\title{
Potentiation of Erythropoiesis In Vitro by Dexamethasone
}

\author{
Davm W. Golde, Noelle Bersch, and Martin J. Clune \\ From the Division of Hematology-Oncology, Department of Medicine, School \\ of Medicine, University of California, Los Angeles, California 90024
}

\begin{abstract}
A B S T R A C T The effect of dexamethasone on erythropoiesis was examined in vitro. Hematopoietic cells from 13-day mouse fetal livers were cultured for $48 \mathrm{~h}$ in the presence or absence of erythropoietin and erythroid colonies enumerated. Colony formation occurring in cultures containing no added erythropoietin was inhibited by the incorporation of antierythropoietin antibody, suggesting that these colonies formed in response to endogenous hepatic erythropoietin. Maximal colony formation was observed with $0.5 \mathrm{U} / \mathrm{ml}$ of sheep erythropoietin. Dexamethasone increased erythroid colony formation with peak stimulation at $10^{-8} \mathrm{M}$. Dexamethasone potentiation was most marked in cultures containing less than maximally stimulating concentrations of erythropoietin. The cells required only a brief exposure to glucocorticosteroid to exhibit the augmented cloning capacity, and dexamethasone stimulation was inhibited by progesterone $\left(10^{-6} \mathrm{M}\right)$. A comparable response to dexamethasone was observed in cultures of adult murine and human bone marrow erythroid progenitors, implying that the phenomenon is not peculiar to fetal cells and is not dependent on the presence of fetal hepatocytes. These data suggest that erythroid progenitor cells possess a glucocorticoid receptor mechanism that can modulate the response to erythropoietin in vitro.
\end{abstract}

\section{INTRODUCTION}

Although erythropoietin is the primary humoral regulator of red blood cell production in mammals, relatively little is known about the factors modulating the interaction of erythropoietin with target cells (1). Erythropoietin presumably interacts with a receptor on the surface of certain red cell progenitors (2). Stimulation of these erythropoietin-sensitive cells results in a series of replicative and maturational steps culminating in the production of mature erythrocytes. Various hormones are known to influence hematopoiesis (3). Androgenic

Received for publication 24 June 1975 and in revised form 18 August 1975. steroids and other steroids with a $5 \beta-\mathrm{H}$ configuration increase red cell production both in vivo and in vitro by direct and indirect mechanisms (4). Androgenic steroids appear to stimulate granulopoiesis as well $(5,6)$.

The role of glucocorticosteroids in erythropoiesis is uncertain. Glucocorticoids have been used in the treatment of aplastic anemia and may improve red cell production in a congenital abnormality of erythropoiesis (Diamond-Blackfan syndrome). We report here that dexamethasone potentiates the erythropoietin-stimulated proliferation of red cell progenitors in vitro. The dexamethasone effect may involve an augmented sensitivity of progenitor cells to erythropoietin in vitro.

\section{METHODS}

Fetuses of white Swiss-Webster mice were obtained at $12 \frac{1}{2}$ $13 \frac{1}{2}$ days' gestation. The fetal livers were dissected out and single cell suspensions prepared by repeated aspiration through a no. 25 needle. The method of Iscove et al. (7) was used for cloning erythroid progenitors in vitro. Cells were plated in enriched alpha medium with $30 \%$ fetal calf serum and antibiotics, with a supporting matrix of $0.8 \%$ methyl cellulose. Dithiothreitol $\left(10^{-4} \mathrm{M}\right)$ or $\alpha$-thioglycerol $\left(10^{-4} \mathrm{M}\right)$ was included in all plates $(8,9)$. For most experiments, $10^{4}$ viable nucleated cells were dispersed in $1-\mathrm{ml}$ cultures in $35-\mathrm{mm}$ plastic dishes (Falcon Plastics, Division of Bioquest, Oxnard, Calif.). Additions to the cultures included Step 3 sheep plasma erythropoietin (Connaught Laboratories, Toronto, Canada) and human urinary erythropoietin (provided by the Blood Resources Division, Heart and Lung Institute, National Institutes of Health). Dexamethasone, prednisone, and progesterone (Sigma Chemical Co., St. Louis, Mo.) were dissolved in $100 \%$ ethanol and diluted to appropriate concentrations with complete tissue culture medium. Control cultures were prepared containing equivalent concentrations of ethanol. Rabbit antierythropoietin antibody was a gift of Dr. A. Ichiki, Knoxville, Tenn. The cultures were incubated at $37^{\circ} \mathrm{C}$ in a humidified atmosphere of $5 \% \mathrm{CO}_{2}$ in air for $48 \mathrm{~h}$. Erythroid colonies of eight cells or more were enumerated by using an inverted microscope. Colonies were stained with benzidine after transfer to slides to confirm their erythroid nature (7). Similar cultures were prepared with young adult SwissWebster mouse bone marrow. Normal human bone marrow was obtained from informed volunteers by aspiration and the nucleated cells were isolated by centrifugation in Wintrobe tubes. The same culture technique was used for 
TABLE I

Fetal Liver Erythroid Colony Formation In Vitro

\begin{tabular}{|c|c|}
\hline Addition to plate & CFU-E \\
\hline & per 104 cells \\
\hline 一 & 34 \\
\hline $0.5 \mathrm{U}$ erythropoietin & 176 \\
\hline $100 \mu$ l antierythropoietin antibody & 4 \\
\hline $\begin{array}{l}100 \mu \mathrm{l} \text { antierythropoietin antibody } \\
\quad+0.5 \mathrm{U} \text { erythropoietin }\end{array}$ & 20 \\
\hline $\begin{array}{l}\text { Ethanol control (equivalent to } \\
10^{-3} \mathrm{M} \text { dexamethasone) }\end{array}$ & 30 \\
\hline Normal rabbit serum control & 32 \\
\hline
\end{tabular}

human cells (7). In the experiments with bone marrow $10^{5}$ cells were plated. The progenitor cell yielding the red cell colonies is referred to as "CFU-E" (colony-forming unit, erythroid $)^{1}(10,11)$.

\section{RESULTS}

Some erythroid colonies developed from fetal mouse liver cells plated in methyl cellulose containing no added erythropoietin. The addition of antierythropoietin antibody largely abrogated this spontaneous colony formation (Table I), suggesting that these colonies formed in response to endogenous erythropoietin produced by the fetal liver (12-14) or perhaps also to erythropoietin in the fetal calf serum. Erythropoietin-stimulated erythroid colonies in fetal liver hematopoietic cell cultures were found to be linearly related to the number of cells plated. Dose-response curves consistently showed maximum colony formation with $0.5 \mathrm{U}$ of sheep erythropoietin (Table II). At this dose, colony formation was increased approximately fivefold over control cultures. $100 \mu \mathrm{l}$ of antierythropoietin antibody serum reduced the erythropoietin-stimulated colony formation to below control levels (Table I). A series of culture experiments were run to test for the effect of ethanol. Ethanol, in concen-

${ }^{1}$ Abbreviation used in this paper: CFU-E, colony-forming unit, erythroid.

TABLE II

Erythropoietin Dose Response

\begin{tabular}{cc}
\hline Erythropoietin & CFU-E \\
\hline$U$ & per 10* cells \\
0 & $29(20-37)$ \\
0.01 & $62(56-68)$ \\
0.05 & $115(102-128)$ \\
0.10 & $142(124-160)$ \\
0.50 & $230(187-272)$ \\
1.00 & $166(108-224)$ \\
\hline
\end{tabular}

Mean and range are given for two experiments performed in duplicate with sheep erythropoietin.

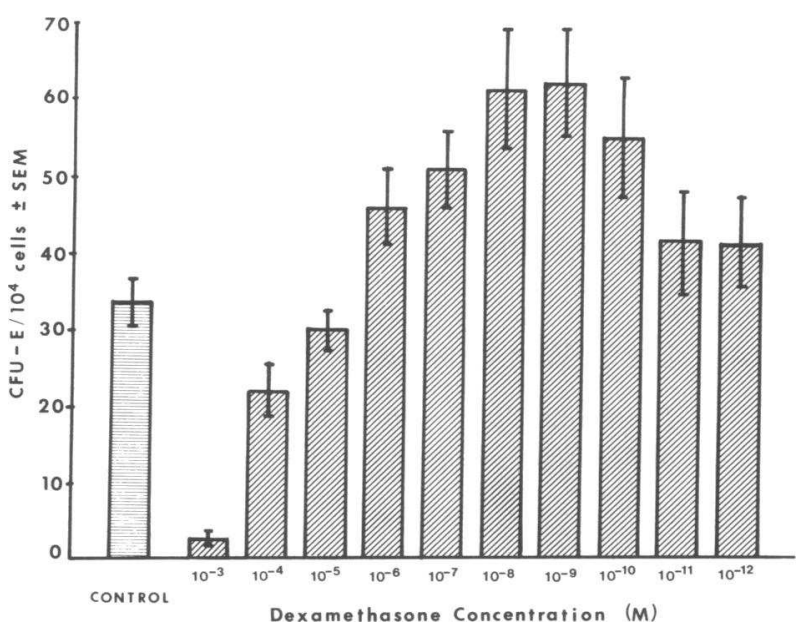

Figure 1 Effect of dexamethasone on erythroid colony formation (CFU-E). Plates contain no added erythropoietin. Bars give the mean values of six experiments and bracketed lines the standard error of the mean.

trations equivalent to dilutions yielding $10^{-3} \mathrm{M}$ dexamethasone, had no detectable effect on erythroid colony formation (Table I).

In plates not containing added erythropoietin, dexamethasone caused an increase in fetal erythroid colony formation over a wide range of concentrations (Fig. 1). Dexamethasone inhibited colony formation at concentra-

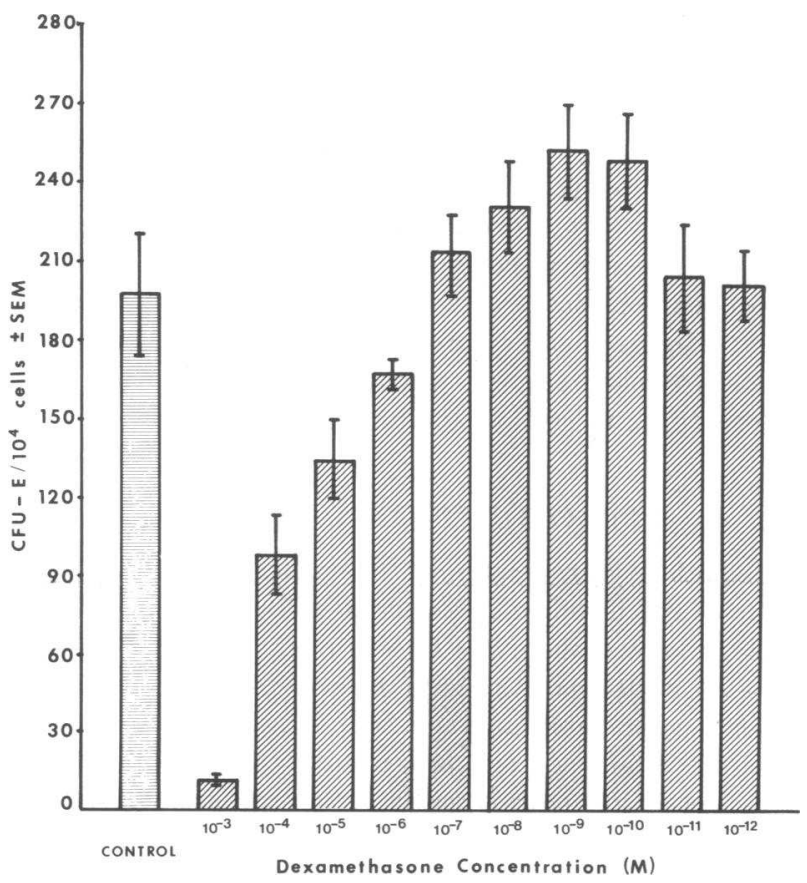

FIGURE 2 Effect of dexamethasone on erythroid colony formation (CFU-E). Plates contain $0.5 \mathrm{U}$ sheep plasma erythropoietin. Bars give the mean values of six experiments and bracketed lines the standard error of the mean. 
TABLE III

Effect of Prednisone on Erythropoietin-Stimulated Fetal Liver Erythroid Colony Formation

\begin{tabular}{cc}
\hline Prednisone & CFU-E \\
\hline$M$ & per/104 cells \\
- & 120 \\
$10^{-3}$ & 60 \\
$10^{-6}$ & 164 \\
$10^{-7}$ & 180 \\
$10^{-8}$ & 128 \\
$10^{-9}$ & 110 \\
\hline
\end{tabular}

Cultures contain $0.5 \mathrm{U}$ sheep erythropoietin.

tions greater than $10^{-6} \mathrm{M}$. Stimulation was observed between $10^{-6} \mathrm{M}$ and $10^{-10} \mathrm{M}$, with peak effect (mean of $82 \%$ stimulation) noted at $10^{-6} \mathrm{M}$ (Fig. 1).

In the presence of maximally stimulating concentrations of erythropoietin, the dexamethasone effect on numbers of CFU-E was less pronounced. With $10^{-6} \mathrm{M}$ dexamethasone, colony formation increased by a mean of $27 \%$ in the presence of $0.5 \mathrm{U}$ of sheep erythropoietin (Fig. 2). A similar pattern was observed with prednisone, though peak stimulation occurred at $10^{-7} \mathrm{M}$ ( $\mathrm{Ta}$ ble III).

The glucocorticoid stimulation of erythroid colony formation in vitro did not require that the hormone be present in the tissue culture plate. The effect was observed when the cells were exposed to dexamethasone for $1 \mathrm{~h}$, washed, and then plated. Since progesterone is known to block glucocorticoid binding to the receptors of other types of cells (15) and interfere with the transport of the receptor complex to the nucleus (16), experiments were performed to ascertain the effect of simultaneously added progesterone on the glucocorticoid stimulation of erythropoiesis. Progesterone $\left(10^{-6} \mathrm{M}\right)$ was found to abrogate the glucocorticoid effect on the numbers of fetal erythroid colonies (Table IV). This

TABLE IV

Effect of Dexamethasone, Progesterone, and Erythropoietin on Erythroid Colony Formation (Fetal Liver Erythroid Cells)

\begin{tabular}{cccc}
\hline Dexamethasone & Progesterone & Erythropoietin & CFU-E \\
\hline$M$ & $M$ & $U$ & per $10^{4}$ cells \\
- & - & - & 40 \\
$10^{-9}$ & - & - & 88 \\
- & $10^{-6}$ & - & 48 \\
$10^{-9}$ & $10^{-6}$ & - & 48 \\
- & - & 0.5 & 144 \\
$10^{-9}$ & - & 0.5 & 232 \\
$10^{-9}$ & $10^{-6}$ & 0.5 & 136 \\
- & $10^{-6}$ & 0.5 & 144 \\
\hline
\end{tabular}

TABLE V

Effect of Dexamethasone $\left(10^{-9} M\right)$ on Erythropoietin Dose Response (Fetal Liver Erythroid Cells)

\begin{tabular}{cccc}
\hline & \multicolumn{2}{c}{ CFU-E } & \\
\cline { 2 - 3 } Erythropoietin & Dexamethasone & Control & $\begin{array}{c}\% \\
\text { augmentation* }\end{array}$ \\
\cline { 2 - 3 }$U$ & per 10. cells & \\
0 & 44 & 20 & 120 \\
0.01 & 120 & 68 & 77 \\
0.05 & 236 & 128 & 84 \\
0.10 & 264 & 160 & 65 \\
0.50 & 300 & 272 & 10 \\
1.00 & 268 & 224 & 20 \\
2.00 & 236 & 192 & 22 \\
\hline
\end{tabular}

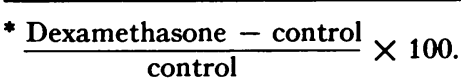

effect was observed in cultures containing no erythropoietin as well as in those containing maximally stimulating concentrations of erythropoietin. Progesterone itself at $10^{-6} \mathrm{M}$ was found to have no effect on erythropoiesis but was toxic at $10^{-3} \mathrm{M}$.

In an attempt to define the mechanism of dexamethasone-stimulated erythropoiesis, erythropoietin dose-response experiments were repeated with and without dexamethasone $\left(10^{-6} \mathrm{M}\right)$. These studies showed that the glucocorticoid augmentation of erythropoiesis was greatest at levels of erythropoietin below those causing maximal stimulation (Table V). Similar phenomena were observed with human and sheep erythropoietin. Dexamethasone did not increase erythroid colony formation in the cultures containing antierythropoietin antibody (Table VI), implying that the steroid had no direct stimulatory effect.

Studies were performed with adult mouse bone marrow in order to be certain that the observations were not peculiar to the fetal liver hematopoietic cell cul-

TABLE VI

Effect of Antierythropoietin Antibody on Dexamethasone Response (Fetal Liver Erythroid Cells)

\begin{tabular}{cccc}
\hline Erythropoietin & $\begin{array}{c}\text { Antierythropoietin } \\
\text { antibody }\end{array}$ & Dexamethasone & CFU-E \\
\hline$U$ & $\mu l$ & $M$ & per 104 cells \\
- & - & - & 48 \\
- & 50 & - & 24 \\
- & - & $10^{-9}$ & 88 \\
- & 50 & $10^{-9}$ & 28 \\
0.5 & - & - & 180 \\
0.5 & 100 & - & 44 \\
0.5 & 50 & - & 124 \\
0.5 & - & $10^{-9}$ & 244 \\
0.5 & 50 & $10^{-9}$ & 116 \\
\hline
\end{tabular}

Dexamethasone Potentiation of Erythropoiesis 
TABLE VII

Effect of Dexamethasone on Adult Mouse Marrow CFU-E

\begin{tabular}{lc}
\hline & CFU-E \\
\hline & per $10^{5}$ cells \\
Control & $3 \pm 2$ \\
Dexamethasone $\left(10^{-9} \mathrm{M}\right)$ & $10 \pm 2$ \\
Erythropoietin $(0.5 \mathrm{U})$ & $140 \pm 24$ \\
Erythropoietin $(0.5 \mathrm{U})+$ dexamethasone $\left(10^{-9} \mathrm{M}\right)$ & $191 \pm 33$ \\
Erythropoietin $(0.5 \mathrm{U})$ & 95 \\
Erythropoietin $(0.5 \mathrm{U})+$ dexamethasone $\left(10^{-9} \mathrm{M}\right)$ & 140 \\
Erythropoietin $(0.5 \mathrm{U})+$ dexamethasone $\left(10^{-9} \mathrm{M}\right)+$ progesterone $\left(10^{-6} \mathrm{M}\right)$ & 100 \\
\hline
\end{tabular}

$\mathrm{Mean} \pm \mathrm{SE}$ given for seven experiments, plates contain $\alpha$-thioglycerol $\left(10^{-4} \mathrm{M}\right)$.

ture system. Murine marrow cells showed an erythropoietin dose-response effect like that of fetal liver cells. Maximal stimulation occurred at $0.5 \mathrm{U}$ of sheep erythropoietin. Dexamethasone $\left(10^{-0} \mathrm{M}\right)$ caused a substantial number of colonies to appear in cultures not containing added erythropoietin (Table VII). The dexamethasoneinduced augmentation of cloning in cultures to which erythropoietin was added was comparable to that seen in the fetal liver experiments and the dexamethasone effect was blocked by progesterone (Table VII).

Human bone marrow erythroid colony formation was also increased in the presence of dexamethasone $\left(10^{-\circ}\right.$ M) (Table VIII). The degree of augmentation at maximal stimulating levels of erythropoietin was comparable to the results obtained with murine tissues.

\section{DISCUSSION}

Although the $5 \beta-\mathrm{H}$ steroids are known stimulators of red cell production $(4,17)$, the relationship of glucocorticosteroids to erythropoiesis is uncertain. Addison's disease in man is associated with normocytic, normochromic anemia (18), and a congenital erythroid hy-

\section{TABLE VIII}

Effect of Dexamethasone on Human Bone Marrow CFU-E

\begin{tabular}{lc}
\hline & CFU-E \\
\hline & per $10^{5}$ cells \\
Control & $5(0-9)$ \\
Dexamethasone $\left(10^{-9} \mathrm{M}\right)$ & $19(16-22)$ \\
Erythropoietin & \\
$0.01 \mathrm{U}$ & $25(12-37)$ \\
$0.05 \mathrm{U}$ & $32(14-49)$ \\
$0.1 \mathrm{U}$ & $42(22-62)$ \\
$0.5 \mathrm{U}$ & $48(26-70)$ \\
$1.0 \mathrm{U}$ & $60(34-84)$ \\
$1.0 \mathrm{U}+$ dexamethasone $\left(10^{-9} \mathrm{M}\right)$ & $74(54-93)$ \\
\hline
\end{tabular}

Mean and range of two experiments performed in duplicate with human urinary erythropoietin. poplasia of children (Diamond-Blackfan syndrome) is frequently responsive to low doses of glucocorticoids (19). In animals, glucocorticosteroids and ACTH have been reported to stimulate erythropoiesis $(20-22)$ but inhibition has also been observed $(23,24)$ On the basis. of observations in nephrectomized rats, Malgor and coworkers (22) concluded that dexamethasone stimulated erythropoiesis by an effect on erythropoietin production. Glucocorticoids are also reported to stimulate erythropoiesis in amphibians (25). Cortisone has been found inhibitory to granulopoiesis both in vivo and in vitro (26).

Mouse fetal liver is a rich source of erythropoietinresponsive cells (27) and has been used in assays for erythropoietin (28). We used a cloning assay employing fetal liver cells in order to assess the effect of dexamethasone on mammalian erythropoiesis in vitro. Erythroid colonies formed in vitro without the addition of exogenous erythropoietin. Since these colonies did not form when an antibody to erythropoietin was included in the culture plate, we assumed that these colonies were generated in response to endogenous erythropoietin produced by the fetal liver cells (12-14) or perhaps in part to erythropoietin in the fetal calf serum. Exogenous erythropoietin markedly stimulated colony formation in vitro, and peak activity was observed at a concentration of $0.5 \mathrm{U} / \mathrm{ml}$ sheep erythropoietin. Higher doses of sheep erythropoietin yielded fewer colonies and this may have been due to toxic impurities in the erythropoietin preparation ( 7 ).

Dexamethasone produced a marked augmentation of colony formation in vitro. The dexamethasone-induced increased cloning was most prominent at suboptimal levels of erythropoietin. It seems likely that the dexamethasone effect was mediated via a glucocorticosteroid receptor mechanism in the erythropoietin-responsive cells. Only a brief exposure to steroid was required to exhibit the stimulatory effect and the dexamethasone stimulation was ablated by appropriate concentrations 
of progesterone. Progesterone is known to block glucocorticoid activity by interfering with glucocorticoid receptor binding and function $(15,16)$. Also, dexamethasone did not increase colony formation in the presence of antierythropoietin antibody.

Erythropoietin is thought to act via a specific receptor mechanism on certain red cell progenitors $(2,27)$. The present studies suggest that these cells may also have a glucocorticoid receptor mechanism. The addition of dexamethasone appears to increase the sensitivity and response to erythropoietin in vitro and does so maximally in concentrations equivalent to physiologic levels of hydrocortisone. The comparable response of adult mouse and human marrow erythroid progenitors to dexamethasone implies that the phenomenon is not peculiar to fetal cells and is not dependent on the presence of fetal hepatocytes in the culture plates. One possible explanation for these observations is that there is an interaction between the postulated receptor mechanism for glucocorticosteroid and erythropoietin on red cell progenitors. Glucocorticosteroid modulation of the interaction between hormones and their receptor mechanisms has been described in several systems. Recently, glucocorticoids were shown to modulate the sensitivity of the rat testicular Leydig cell to chorionic gonadotropin (hCG) (29). Gospodarowicz demonstrated a permissive effect of glucocorticoid on the stimulation of 3T3 cells by fibroblast growth factor (30). Progesterone was inhibitory in the 3T3 system as well.

Since concentrations of dexamethasone higher than those equivalent to physiologic concentrations of hydrocortisone did not augment erythropoiesis, there is little in these in vitro experiments to suggest that glucocorticoids would be of use as a "general" stimulus to erythropoiesis. On the other hand, diseases involving alterations in the function or interaction of these postulated receptor mechanisms might be affected by exogenous glucocorticosteroid.

\section{ACKNOWLEDGMENTS}

This study was supported by U. S. Public Health Service grants CA 15688, CA 15619, and RR 00865, American Cancer Society grant CI-60B, and a grant from the California Institute for Cancer Research.

\section{REFERENCES}

1. Krantz, S. B., and L. O. Jacobson. 1970. Erythropoietin and the Regulation of Erythropoiesis. University of Chicago Press, Chicago. 330 pp.

2. Chang, S. C-S., D. Sikkema, and E. Goldwasser. 1974. Evidence for an erythropoietin receptor protein on rat bone marrow cells. Biochem. Biophys. Res. Commun. $57: 399-405$.

3. Wintrobe, M. M., G. R. Lee, D. R. Boggs, T. C. Bithell, J. W. Athens, and J. Foerster. 1974. Clinical Hematology. Lea \& Febiger, Philadelphia. 7th edition. 1896 pp.
4. Shahidi, N. T. 1973. Androgens and erythropoiesis. $N$ Engl. J. Med. 289 : 72-80.

5. Horn, Y., and D. C. Price. 1972. The effect of androgens on erythroid and granulocytic marrow recovery in the irradiated rat. Acta Haematol. (Basal). 48: 300-306.

6. Rosenblum, A. L., and P. P. Carbone. 1974. Androgenic hormones and human granulopoiesis in vitro. Blood. 43 : 351-356.

7. Iscove, N. N., F. Sieber, and K. H. Winterhalter. 1974. Erythroid colony formation in cultures of mouse and human bone marrow: analysis of the requirement for erythropoietin by gel filtration and affinity chromatography on agarose-concanavalin A. J. Cell. Physiol. 83: 309-320.

8. Toohey, J. I. 1975. Sulfhydryl dependence in primary explant hematopoietic cells. Inhibition of growth in vitro with vitamin $\mathrm{B}_{12}$ compounds. Proc. Natl. Acad. Sci. U.S. A. 7.3: 72-77.

9. Iscove, N. N., and F. Sieber. 1975. Erythroid progenitors in mouse bone marrow detected by macroscopic colony formation in culture. Exp. Hematol. (Copenh.). 3: 3243.

10. Stephenson, J. R., A. A. Axelrad, D. L. McLeod, and M. M. Shreeve. 1971. Induction of colonies of hemoglobin-synthesizing cells by erythropoietin in vitro. Proc. Natl. Acad. Sci. U. S. A. 68: 1542-1546.

11. Gregory, C. J., E. A. McCulloch, and J. E. Till. 1973. Erythropoietic progenitors capable of colony formation in culture: state of differentiation. J. Cell. Physiol. 81: 411-420.

12. Schooley, J. C., and L. J. Mahlmann. 1974. Extrarenal erythropoietin production by the liver in the weanling rat. Proc. Soc. Exp. Biol. Med. 145 : 1081-1083.

13. Fried, W. 1972. The liver as a source of extrarenal erythropoietin production. Blood. 40:671-677.

14. Zanjani, E. D., L. I. Mann, H. Burlington, A. S. Gordon, and L. R. Wasserman. 1974. Evidence for a physiologic role of erythropoietin in fetal erythropoiesis. Blood. 44 : 285-290.

15. Rousseau, G. G., J. D. Baxter, and G. M. Tomkins. 1972. Glucocorticoid receptors: relations between steroid binding and biological effects. J. Mol. Biol. 67: 99-115.

16. Rousseau, G. G., J. D. Baxter, S. J. Higgins, and G. M. Tomkins. 1973. Steroid-induced nuclear binding of glucocorticoid receptors in intact hepatoma cells. J. Mol. Biol. 79 : 539-554.

17. Mizoguchi, H., and R. D. Levere. 1971. Enhancement of heme and globin synthesis in cultured human marrow by certain $5 \beta-\mathrm{H}$ steroid metabolites. J. Exp. Med. $134: 1501-1512$.

18. Báez-Villaseñor, J., C. E. Rath, and C. A. Finch. 1948. The blood picture in Addison's disease. Blood. 3: 769773.

19. Diamond, L. K., D. M. Allen, and F. B. Magill. 1961. Congenital (erythroid) hypoplastic anemia. A 25-year study. Am. J. Dis. Child. 102: 403-415.

20. Pospísil, M., I. Zakopalová, and J. Netíková. 1972. The effect of hydrocortisone pretreatment upon erythropoietic recovery after a single sublethal $\mathrm{X}$-ray exposure of mice. Folia Biol. (Prague). 18: 284-291.

21. Peschle, C., G. F. Sasso, G. Mastroberardino, and M. Condorelli. 1971. The mechanism of endocrine influences on erythropoiesis. J. Lab. Clin. Med. 78: 20-29.

22. Malgor, L. A., P. R. Torales, E. Klainer, L. Barrios, and C. C. Blanc. 1974. Effects of dexamethasone on bone marrow erythropoiesis. Horm. Res. (Basel). 5: 269-277.

Dexamethasone Potentiation of Erythropoiesis 
23. Gordon, A. S., E. A. Mirand, and E. D. Zanjani. 1967. Mechanisms of prednisolone action in erythropoiesis. Endocrinology. 81: 363-368.

24. Cardinali, G., G. Cardinali, B. M. DeCaro, A. H. Handler, and M. Aboul-Enein. 1964. Effect of high doses of cortisone on bone marrow cell proliferation in the Syrian hamster. Cancer Res. 24: 969-972.

25. Meints, R. H., and F. J. Carver. 1973. Triiodothyronine and hydrocortisone effects on Rana pipiens erythropoiesis. Gen. Comp. Endocrinol. 21: 9-15.

26. Metcalf, D. 1969. Cortisone action on serum colonystimulating factor and bone marrow in vitro colonyforming cells. Proc. Soc. Exp. Biol. Med. 132: 391-394.
27. Cantor, L. N., A. J. Morris, P. A. Marks, and R. A. Rifkind. 1972. Purification of erythropoietin-responsive cells by immune hemolysis. Proc. Natl. Acad. Sci. U. S. A. $69: 1337-1341$.

28. Wardle, D. F. H., I. Baker, J. S. Malpas, and P. F. M. Wrigley. 1973. Bioassay of erythropoietin using foetal mouse liver cells. Br. J. Haematol. 24: 49-56.

29. Engel, W., and J. Frowein. 1974. Glucocorticoids and hCG sensitivity of rat testicular Leydig cell. Nature (Lond.). 251 : 146-148.

30. Gospodarowicz, D. 1974. Localisation of a fibroblast growth factor and its effect alone and with hydrocortisone on 3T3 cell growth. Nature (Lond.). 249: 123-127. 